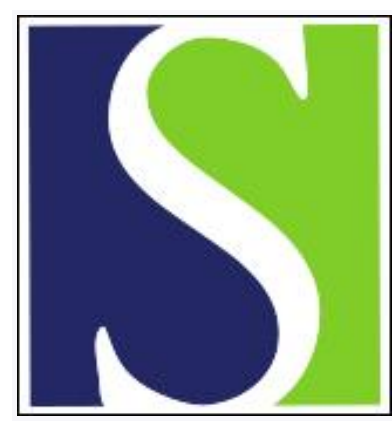

Scand J Work Environ Health 1985;11(3):181-187

https://doi.org/10.5271/sjweh.2236

Issue date: Jun 1985

Occupational cancer. Where now and where next?

by Roe FJ

The following article refers to this text: 1986;12(1):75-77

Key terms: alcohol; asbestos; cancer; diet; hormone; hygiene; occupational cancer; overnutrition; record; surveillance; tobacco

This article in PubMed: www.ncbi.nlm.nih.gov/pubmed/4035320

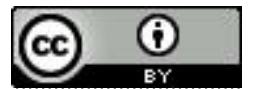




\title{
Occupational cancer
}

\section{Where now and where next?}

\author{
by Francis JC Roe, DM(Oxon) DSc(Lond) FRC Path ${ }^{1}$
}

\begin{abstract}
ROE FJC. Occupational cancer: Where now and where next? Scand Environ J Work Health 11 (1985) 181-187. For each kind of occupationally associated cancer, there are three distinct stages in the development of the problem: recognition of a possible problem, confirmation, and the introduction of preventive measures. In the past, recognition of a possible problem depended heavily on chance and on the powers and observation of dedicated physicians and surgeons. Confirmation consisted of the collection of further anecdotal evidence and the conduct of case-referent (case-control) or other studies. The introduction of preventive measures often lagged woefully behind confirmation that a problem existed. Recently, the power of epidemiology as a primary investigative tool has grown to the point where unsuspected associations between occupation and cancer risk may be the first hint that a problem exists. However, it is important to recognize that investigative epidemiology is capable of constructing misleading pictures. In the future there is bound to be continuing pressure to reduce maximal permissible exposure to proven carcinogens. For chemicals for which there is no more than suspicion based on laboratory tests, one must ensure that regulatory action is based on good science, sound judgement, and common sense, rather than on the machinations of those with vested interests, of ambitious lawyers, or of the lunatic fringe. Less than $10 \%$ of all cancers are likely to be due to occupational factors. Therefore, even turning the world upside down with safety precautions against actual and suspected carcinogens would only marginally affect the present human cancer burden.
\end{abstract}

Key terms: alcohol, asbestos, diet, hygiene, hormones, overnutrition, records, surveillance, tobacco.

In this brief discussion, rather than catalogue the history of occupational cancer, I have chosen to address philosophical issues which might provide some guidance as to where we should go in the future.

Notwithstanding the long established associations between exposure to soot or to mineral oil and an increased incidence of cancer of the scrotum and between exposure to aromatic amines in the dye-stuff industry and an increased incidence of cancer of the urinary bladder, it was not until the 1960s that cancers in general came to be regarded as potentially preventible. Prior to that time most cancers were regarded in the eyes of the general public as "acts of God" or "misfortunes of fate." Two kinds of information served to bring about the revolution in thinking. First, there came the epidemiologic evidence that incidences of various kinds of cancer are quite different in different countries (table 1) and that, when people migrate from one environment to another, the spectrum of cancers among them, and even more so among their children, becomes progressively more and more like that for their adoptive country (table 2). Second, laboratory studies revealed that numerous chemical substances can increase the incidences of various kinds of cancer among laboratory animals.

In light of information of these two kinds, it became increasingly accepted from the 1960s on that

\footnotetext{
1 Independent Consultant, 19 Marryat Road, Wimbledon Common, London, SW19 5BB, England.
}

Reprint requests to: Dr FJC Roe, 19 Marryat Road, Wimbledon Common, London, SW19 5BB, England. environmental factors are more important than genetic ones as determinants of cancer risk. However, misunderstandings arose and some theorists began to go well beyond the facts. In particular, they quite unjustifiably assumed that Mother Nature is incapable of causing cancer and that the only environmental factors capable of doing so are man-made chemicals. Based on this false conception, a long and accusing finger began to be pointed at industries which make or expose their workforce to synthetic chemicals and/or which release such chemicals into the general environment.

There is, of course, much more to the environment than exposure to man-made chemicals. There is, for instance, the vast spectrum of natural things that we eat. It is clear that the amount we eat, as distinct from what we eat, is an important determinant of

Table 1. Geographic variation in cancer incidence in the age range $35-64$ years $(3)$.

\begin{tabular}{|c|c|c|c|}
\hline Site & $\begin{array}{l}\text { High } \\
\text { incidence } \\
\text { area }\end{array}$ & $\begin{array}{l}\text { Low } \\
\text { incidence } \\
\text { area }\end{array}$ & $\begin{array}{l}\text { Incidence } \\
\text { ratio }\end{array}$ \\
\hline $\begin{array}{l}\text { Skin } \\
\text { Esophagus } \\
\text { Bronchus }\end{array}$ & $\begin{array}{l}\text { Queensland } \\
\text { Northeast Iran } \\
\text { United } \\
\text { Kingdom }\end{array}$ & $\begin{array}{l}\text { Bombay } \\
\text { Nigeria } \\
\text { Nigeria }\end{array}$ & $\begin{array}{r}>200 \\
300 \\
35\end{array}$ \\
\hline $\begin{array}{l}\text { Stomach } \\
\text { Liver }\end{array}$ & $\begin{array}{l}\text { Japan } \\
\text { Mozambique }\end{array}$ & $\begin{array}{l}\text { Uganda } \\
\text { United } \\
\text { Kingdom }\end{array}$ & $\begin{array}{r}25 \\
100\end{array}$ \\
\hline Prostate & $\begin{array}{l}\text { United States } \\
\text { (Black) }\end{array}$ & Japan & 40 \\
\hline Penis & Uganda & Israel & 300 \\
\hline
\end{tabular}


Table 2. Changes in cancer risk for Japanese men who migrate to the United States (5).

\begin{tabular}{|c|c|c|c|c|}
\hline \multirow[b]{2}{*}{ Type of cancer } & \multicolumn{4}{|c|}{ Standardized mortality ratios (Japan $=100$ ) } \\
\hline & Japanese-born & $\begin{array}{c}\text { Japanese-born } \\
\text { migrants } \\
\text { to the United States }\end{array}$ & $\begin{array}{c}\text { American-born } \\
\text { Japanese }\end{array}$ & $\begin{array}{c}\text { American } \\
\text { white }\end{array}$ \\
\hline $\begin{array}{l}\text { Stomach } \\
\text { Colon } \\
\text { Lung } \\
\text { Leukemia }\end{array}$ & $\begin{array}{l}100 \\
100 \\
100 \\
100\end{array}$ & $\begin{array}{r}72 \\
374 \\
306 \\
314\end{array}$ & $\begin{array}{r}38 \\
288 \\
166 \\
\ldots\end{array}$ & $\begin{array}{r}17 \\
489 \\
316 \\
265\end{array}$ \\
\hline
\end{tabular}

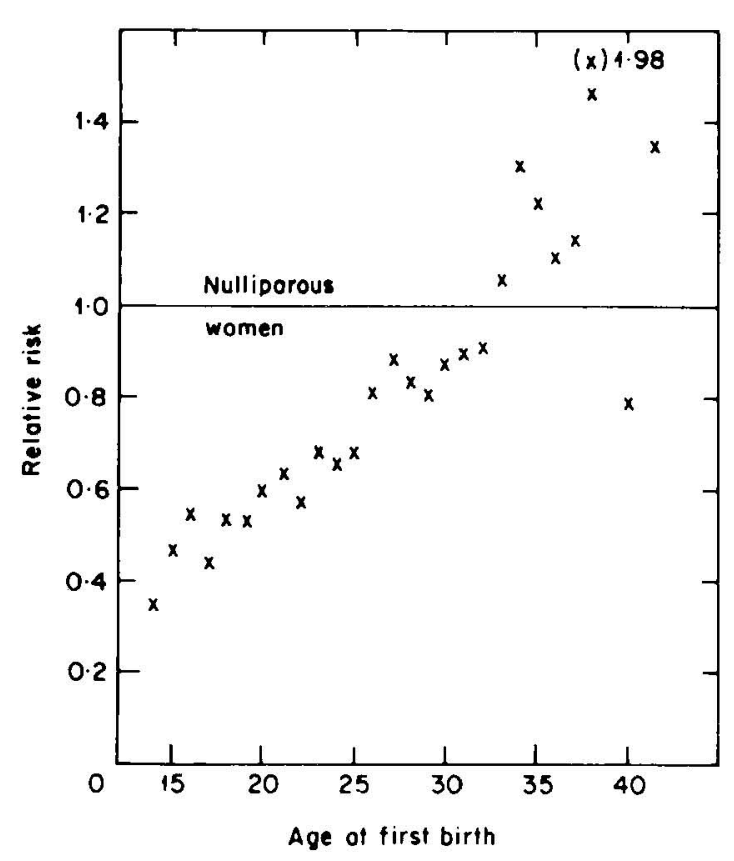

Figure 1. Breast cancer risk according to age at birth of first child (relative to risk of 1.0 for nulliparous women) (9).

Table 3. Estimates of percentages of cancer deaths attributable to occupation and other factors in the United States (4).

\begin{tabular}{|c|c|c|}
\hline & $\begin{array}{c}\text { Best } \\
\text { estimate }\end{array}$ & $\begin{array}{l}\text { Range of } \\
\text { acceptable } \\
\text { estimates }\end{array}$ \\
\hline Occupation & 4 & $2-8$ \\
\hline Industrial products & $<1$ & $1-2$ \\
\hline Pollution & 2 & $1-5$ \\
\hline Diet & 35 & $10-70$ \\
\hline Food additives ${ }^{a}$ & $<1$ & $-5-+2$ \\
\hline Alcohol & 3 & $2-4$ \\
\hline Tobacco & 30 & $25-40$ \\
\hline $\begin{array}{l}\text { Reproductive and sexual } \\
\text { behavior }{ }^{b}\end{array}$ & 7 & $1-13$ \\
\hline Medicine and medical & & \\
\hline procedures & 1 & $0.5-3$ \\
\hline Geophysical factors ${ }^{c}$ & 3 & $2-4$ \\
\hline Infection & 10 & $1-?$ \\
\hline
\end{tabular}

a Antioxidants may be protective.

b Cervix, breast, penis.

c Plus large numbers of nonfatal skin cancers from sunlight. cancer risk. Exposure to background ionizing radiation and to the sun's rays influences cancer risk. Disturbance of endogenous hormonal balance is implicated in the pathogenesis of many kinds of cancer.

Despite the caution which a full consideration of the facts should have engendered, the idea that synthetic chemicals are the main cause of human cancer caught on like wild-fire, especially in the United States. It caught alight in this way for many reasons. It was attractive to those - and that is perhaps all of us - who prefer the natural to the unnatural, who prefer natural colors and flavors to synthetic ones, and who feel that plastics have cheapened the quality of life. It seemed to offer a basis for preventive action. It offered a pulpit for puritans and a platform for politicians. It provided a target for claims for compensation and danger-money and work for lawyers, contract research laboratories, and consultants. Consequently one of the problems now is that large numbers of people and organizations have a vested interest in perpetuating the myth that a high proportion of human cancers is occupational in origin.

It is fascinating to recall that, as long ago as 1700 , the founder of occupational medicine, Ramazzini, reported a higher incidence of breast cancer among nuns than among other women. It is a wonder that no smart American lawyer, on the basis of a contingency fee, has yet tried to persuade a nun that her breast cancer is occupational in origin and that she has a rightful claim against her Mother Superior and her Order! The court proceedings in such a case would make for compulsive television viewing insofar as a successful pregancy before the age of $\mathbf{3 0}$ is one of the best preventives we presently know of in the case of breast cancer (figure 1).

\section{Occupation as a cause of human cancer}

What then is the present position with regard to occupational cancer? An important perspective was recently provided by a survey, conducted by Sir Richard Doll and Richard Peto, of the likely contributions of various factors to the overall cancer incidence in the United States (4). From table 3 it can be seen that their "best estimate," based on an as- 
sessment of a wide variety of information, is that only about $4 \%$ of all deaths from cancers are primarily occupational in origin. Environmental pollution may account for $2 \%$ of cancer deaths, medicines and medical procedures for $1 \%$, and industrial products and food additives each for less than $1 \%$. By comparison the tobacco habit accounts for $30 \%$ of cancer deaths, and various dietary factors probably for as much as $35 \%$.

Even if the proportion of cancer deaths attributable to occupation is only $2 \%$, it provides no basis for complacency. Two percent of all cancer deaths still represents a lot of deaths and a lot of suffering. Nevertheless, it is important that governments and the general public should not be misled by pressure groups into believing that cancer as a disease would largely disappear if the use of all synthetic chemicals were abolished and the chemical, pharmaceutical, and manufacturing industries were done away with in the process.

\section{The insidious nature of carcinogenesis}

A special and serious aspect of carcinogenesis is the insidious way in which the existence of a hazard becomes apparent. The modern industrial use of asbestos began about 100 years ago, and 50 years ago its production and use began to accelerate. According to the International Agency for Research on Cancer (IARC) (7) there was a tenfold increase in its use between 1930 and 1970. Nevertheless, it was not until the mid-1950s that the extent of the cancer risk from asbestos began to be appreciated. But by then we were already amidst the early stages of an epidemic which we were seemingly powerless to prevent. The latency interval for lung cancer secondary to asbestos exposure is upwards of 20 years, depending on the dose and concomitant smoking habits, and the latency interval for mesothelioma is even longer. Therefore people who have been exposed industrially in the past but are now no longer exposed are, nevertheless, still under the ever-increasing risk of developing lung cancer or mesothelioma as they grow older. During the past 20 years or so great strides have been made to improve the standards of occupational hygiene in occupations where asbestos is used. I do not doubt that these have greatly reduced both exposure and cancer risk. However, it could well be another 10 or 20 years before these improvements in hygiene are reflected in a decrease in the incidence of deaths from asbestos-associated lung cancer and mesothelioma. Figure 2, based on figures provided for me by the Health and Safety Executive in the United Kingdom, shows the rise, year by year since 1968, in the number of death certificates in England and Wales in which asbestosis and/or mesothelioma is shown as a cause of death. Up to 1982, the latest year for which full figures are available, the rise was steady and showed no sign of abatement. To these totals

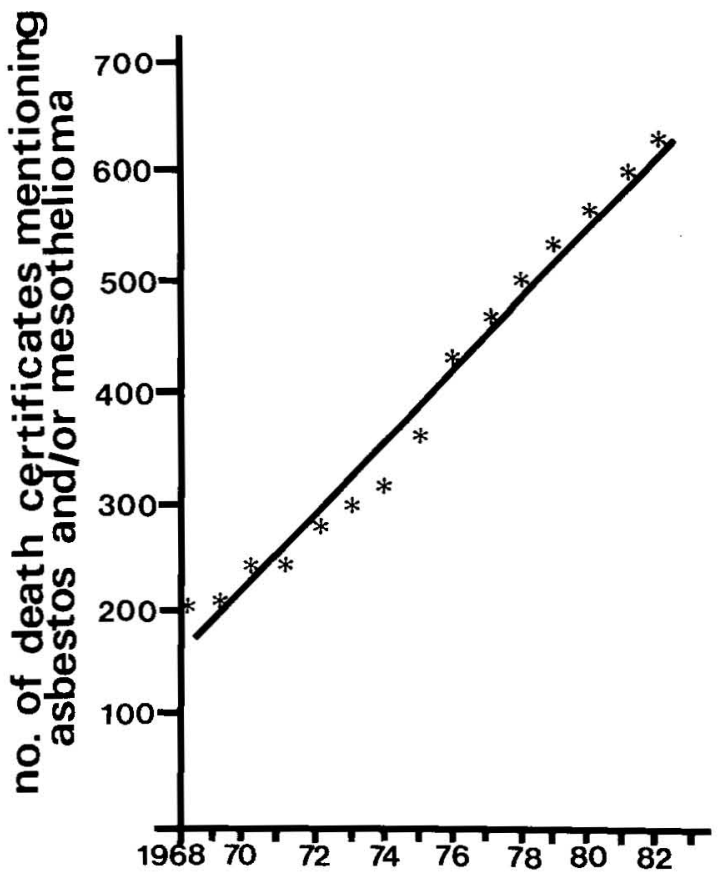

Figure 2. Numbers of death certificates mentioning asbestos and/or mesothelioma in England and Wales during the period 1968-1982.

Table 4. Percentage of change in lung cancer death rates in England and Wales, $1966-1970$ to $1971-1975$ (6).

\begin{tabular}{lcc}
\hline Age group (years) & Men (\%) & Women (\%) \\
\hline $35-39$ & -22 & -16 \\
$40-44$ & -17 & -17 \\
$45-49$ & -4 & +16 \\
$50-54$ & -7 & +17 \\
$55-59$ & -6 & +24 \\
$60-64$ & -5 & +30 \\
$65-69$ & -2 & +23 \\
$70-74$ & +9 & +23 \\
$75-79$ & +21 & +24 \\
$80-84$ & +26 & +31 \\
$\geq 85$ & +26 & +26 \\
\hline All ages & +7 & +27 \\
\hline
\end{tabular}

must be added an unknown number of deaths from asbestos-associated lung cancer, for which asbestosis was not mentioned on the certificate. It is difficult to estimate the contribution of asbestos exposure to lung cancer risk because of the strong association between smoking and cancer at this site.

The overall death rates for lung cancer are, in fact, now falling (table 4), probably because of a decline in the prevalence of smoking and a reduction in the amount of tar delivered by the average cigarette. Despite the overall downturn in the risk of death from lung cancer, we must still expect, on the basis of present trends, there to be about 30000 deaths 
from this cause in men and women in England and Wales during the year $2000 \mathrm{AD}$ (table 5).

Given such data as these, it is obviously necessary to try to take preventive measures before cases of human cancer begin to be seen.

Table 5. Prediction of numbers of deaths from lung cancer in England and Wales based on trends evident in 1982.

\begin{tabular}{|c|c|c|c|c|}
\hline & \multirow{2}{*}{$\frac{\text { Actual }}{1970}$} & \multicolumn{3}{|c|}{ Estimated } \\
\hline & & 1980 & $1990^{a}$ & $2000^{a}$ \\
\hline $\begin{array}{l}\text { Men } \\
\text { Women } \\
\text { Both sexes }\end{array}$ & $\begin{array}{r}24900 \\
5400 \\
30300\end{array}$ & $\begin{array}{r}27000 \\
8200 \\
35500\end{array}$ & $\begin{array}{l}23500 \\
10000 \\
33500\end{array}$ & $\begin{array}{l}18500 \\
11500 \\
30000\end{array}$ \\
\hline
\end{tabular}

a Assuming constant total population and current cohort trends.

\section{Strategy for the prevention of occupational cancer}

During recent years, those endeavoring to prevent further asbestos disasters have tended to give the highest priority to the testing of chemicals for mutagenicity and carcinogenicity. However, in my view, the approach should be broader (figure 3). Although laboratory tests must play an important role, they are not infallible. There are many mechanisms in carcinogenesis, and no one test system is capable of detecting all forms of carcinogenic activity. Asbestos, in fact, gives negative results in most tests for mutagenicity. Moreover, the hazard it presents to man, in the form of risks of lung cancer and mesothelioma, is not, even today, easy to demonstrate in straightforward routine tests for carcinogenicity in animals.

Common sense dictates that all unnecessary exposure to chemicals, particularly inhalable dusts and fumes, should be kept to a minimum. We do not have

1604

\section{A Counterblaste to Tobaco}

3y

Tests - toxicity, mutagenicity, carcinogenicity

3. Monitoring of exposure by trained occupational hygienists

4. Medical surveillance by trained physicians

5. Good records of exposure and health to facilitate epidemiologic studies

Figure 3. Strategy for preventing occupational cancer.

\section{Zi ing I a mes \\ W}

"Bmoking is a custom loatbsome to the epe, hateful to the noge, harmful to the brain, Dangerous to the lungs, and in the blatk stinking fume thereof nearest resembling the borrible stygian smoke of the pit that is bottomless."

Figure 4. The view of King James I of England on the evils of tobacco.

Table 6. Mutagenicity tests in the prediction of carcinogenicity.

\begin{tabular}{|c|c|}
\hline Examples of false-negative results & Reasons for false-positive results in in vitro tests \\
\hline $\begin{array}{l}\text { "Physical" carcinogens (eg, asbestos) } \\
\text { Hormonal carcinogens }\end{array}$ & $\begin{array}{l}\text { Active agents brought into direct contact with deoxyribonucleic } \\
\text { acid in a way that would not happen in vivo }\end{array}$ \\
\hline $\begin{array}{l}\text { Certain metallic compounds (eg, calcium } \\
\text { chromate, cadmium chloride) }\end{array}$ & $\begin{array}{l}\text { Detoxifying mechanisms absent } \\
\text { Repair mechanisms absent }\end{array}$ \\
\hline
\end{tabular}

Table 7. Carcinogenicity tests in animals.

\begin{tabular}{|c|c|}
\hline Reasons for false-negative results & Reasons for false-positive results \\
\hline \multirow[t]{4}{*}{$\begin{array}{l}\text { Species variation absorption, metabolism kinetics, etc. } \\
\text { Impossibility of mimicking human exposure (eg, smoking) }\end{array}$} & $\begin{array}{l}\text { Detoxification pathways overwhelmed by excessive exposure } \\
\text { Inappropriate route of administration }\end{array}$ \\
\hline & $\begin{array}{l}\text { Excessive excretion because high dosage leads to bladder } \\
\text { stones which predispose to bladder tumors }\end{array}$ \\
\hline & $\begin{array}{l}\text { Interference with hormonal or nutritional status by excessive } \\
\text { dosage of test substance or vehicle (eg, pancreatic tumors } \\
\text { from corn oil) }\end{array}$ \\
\hline & $\begin{array}{l}\text { Interference with mineral balance (eg, adrenal medullary } \\
\text { tumors from lactose) }\end{array}$ \\
\hline
\end{tabular}


to wait for the results of laboratory tests before adopting high standards of occupational hygiene. History tells us that good hygiene prevents industrial cancer. Thus there was no epidemic of scrotal cancer among the Swiss chimney sweeps of the 18th and 19th centuries, because they wore protective clothing and kept themselves clean. In the present century, the outbreak of scrotal cancer among automatic lathe operators, who use mineral oils to cool and lubricate cutting edges, is not matched by any comparable outbreak of scrotal cancer in the oil industry, where hygienic standards have traditionally been much higher.

I am not sure whether the well known outburst of King James I against the evils of tobacco (figure 4) was based on common sense or prejudice, but if others had heeded his remarks, there might be a lot less lung cancer about today!

A perception of the need for high standards of occupational hygiene based on knowledge of chemical structure and/or early indications of toxicity might well have led to the prevention of any cases of hepatic angiosarcoma from exposure to vinyl chloride. As it was, acroosteolysis, Raynaud's phenomenon, and other serious toxic effects in workers were first reported by Cordier et al (1), nearly 40 years after vinyl chloride began to be produced commercially. The first report of a cancer risk in man came eight years later (2).

The fact that mutagenicity testing is of no more than limited value for the prediction of carcinogenic potential is now well recognized. I will not, therefore, dwell on the examples of false-negative results or on the reasons for false-positive results listed in table 6.

\section{Overfeeding \\ CPN $\longrightarrow$ Parathyroid hyper- \\ Excess parathormone $\longrightarrow$ 1. Hypercalcemia \\ 2. Metastatic calcification (aorta/kidney) \\ Hypercalcemia \\ Adrenal medullary hyperplasia and neoplasia}

Figure 5. Overteeding and neoplasia of the parathyroid and adrenal medula in rats.
The fact that carcinogenicity tests in animals can also give false-negative and false-positive results is less well known. Of the reasons for false-positive results listed in table 7, the most important are nonspecific enhancement of tumor incidence because of disturbances of hormonal status, nutritional status, or mineral balance. It is undoubtedly true that people in the Western World increase their risk of developing cancer by eating too much, particularly by eating too much fat. However, the association between overeating and cancer risk is even more marked in laboratory rats. Table 8 shows the incidences of certain tumors in untreated control rats in a typical carcinogenicity study. The main effects of the overnutrition in rats are tumors, particularly those of hormonal origin, the pituitary, mammary and adrenal glands. Table 9 illustrates the effect of diet restriction on the incidence of pituitary and mammary tumors in rats, and figure 5 summarizes how overfeeding increases the incidences of parathyroid and adrenal medullary tumors in rats (10). Table 10 compares the common causes of death in humans and laboratory rats. These examples of the role of simple dietary factors in the etiology of neoplasia in rats and the comparative data for humans and rats illustrate the complexity of carcinogenicity and the need for extreme caution in the interpretation of carcinogenicity tests in laboratory animals.

Table 8. Hormone-associated neoplasms (\%) in ad-libitum fed untreated control Sprague Dawley rats observed for up to 26 months (8).

\begin{tabular}{|c|c|c|}
\hline Neoplasm & $\begin{array}{c}\text { Males } \\
(\mathrm{N}=86)\end{array}$ & $\begin{array}{l}\text { Females } \\
(N=86)\end{array}$ \\
\hline Pituitary & 31 & 63 \\
\hline $\begin{array}{l}\text { Adrenal } \\
\text { Cortex } \\
\text { Medulla }\end{array}$ & $\begin{array}{r}2 \\
51\end{array}$ & $\begin{array}{l}7 \\
8\end{array}$ \\
\hline Thyrold, C-cell & 8 & 8 \\
\hline Parathyroid & 0 & 1 \\
\hline $\begin{array}{l}\text { Pancreas } \\
\text { Exocrine } \\
\text { Endocrine }\end{array}$ & $\begin{array}{l}33 \\
16\end{array}$ & $\begin{array}{l}0 \\
9\end{array}$ \\
\hline Testis & 7 & $\ldots$ \\
\hline Ovary & . & 5 \\
\hline $\begin{array}{l}\text { Mammary gland } \\
\text { Fibroadenoma } \\
\text { Adenoma } \\
\text { Other }\end{array}$ & $\begin{array}{l}\ddot{5} \\
\cdots\end{array}$ & $\begin{array}{l}76 \\
12 \\
29\end{array}$ \\
\hline
\end{tabular}

Table 9. Effect of dietary restriction on incidence (\%) of pituitary and mammary tumors in rats (11).

\begin{tabular}{lccrcr}
\hline \multirow{2}{*}{ Tumor } & \multicolumn{2}{c}{ Males } & & \multicolumn{2}{c}{ Females } \\
\cline { 2 - 3 } & Ad-libitum feeding & Restricted feeding & & Ad-libitum feeding & Restricted feeding \\
\hline Pituitary & 32 & $0^{* * *}$ & 0 & 66 & $39^{* *}$ \\
Mammary & 0 & $6^{* * *}$ \\
\hline
\end{tabular}

${ }^{\star *} p<0.01,{ }^{\star * *} p<0.001$. 
Table 10. Percentage of causes of death of humans (aged 15-74 years) and of laboratory rats.

\begin{tabular}{|c|c|c|c|c|}
\hline \multirow{2}{*}{ Cause } & \multicolumn{2}{|c|}{ Humans ${ }^{a}$} & \multicolumn{2}{|c|}{ Rats } \\
\hline & Male & Female & Male & Female \\
\hline \\
\hline Debilitating/fatal & $\cdots$ & $\cdots$ & $60^{\mathrm{b}}$ & $65^{\mathrm{b}}$ \\
\hline \multicolumn{5}{|c|}{$\begin{array}{l}\text { Endocrine, nutritional and metabolic } \\
\text { (except diabetes and deficiency) }\end{array}$} \\
\hline Fatal & 0.2 & 0.5 & & \\
\hline Debilitating/fatal & $\ldots$ & $\cdots$ & $80^{\mathrm{b}}$ & $100^{\mathrm{b}}$ \\
\hline $\begin{array}{l}\text { Neoplasia of all endocrine } \\
\text { sites including pituitary } \\
\text { Pituitary only }\end{array}$ & 0.1 & $\begin{array}{l}\cdots \\
\cdots\end{array}$ & $\begin{array}{l}20^{\mathrm{b}} \\
20.5^{\mathrm{c}}\end{array}$ & $\begin{array}{l}80^{b} \\
40.5^{c}\end{array}$ \\
\hline Neoplasia of the breast & .. & 7.1 & $2.7^{\mathrm{c}}$ & $40.5^{c}$ \\
\hline Ischemic heart disease & 31.9 & 20.6 & 0 & 0 \\
\hline
\end{tabular}

a Mortality data for England and Wales for 1970-1972.

b Typical data for ad-libitum-fed rats.

- Data from 220 male and 220 female ad-libitum-fed, untreated Sprague-Dawley rats which constituted the control groups in two recent carcinogenicity studies.

\section{Need to monitor the work environment}

There is no such thing as nil exposure to anything. The occupational hygienist fulfills many roles in relation to the prevention of industrial cancer. One of the most important of these is to monitor the work environment, first, to ensure that it complies with current regulations with respect to carcinogens and suspect carcinogens and, second, to provide a part of the data base for any ongoing or future epidemiologic survey. Lack of accurate exposure data is presently the greatest handicap in retrospective epidemiology relevant to the investigation of cancer risk. Patterns relating exposure to risk, if they exist, are often hopelessly blurred by the unreliability of exposure data.

The duty of monitoring the factory environment may, in some cases, extend safety of ficers beyond the limits of their training and competence. For this and other reasons, I suspect that it is long overdue for occupational hygiene to be accepted as a specialist profession in its own right, rather than as a technical service to the factory medical department. The role of the safety officer is not one that should be pushed off onto individuals merely because they are adept at paper work or not particularly good at anything else! The responsibilities of occupational hygienists are, nowadays, such that professional training is essential, and commensurate financial reward is indicated.

\section{The role of medical surveillance}

At present there is very much a limit on what a work's medical officer can do in relation to the early diagnosis of industrial cancers or to the identification of precancerous lesions in individuals. There will be a place, in particular situations, for regular chest radiographs, liver function tests, urine cytology, and checks on circulating lymphocytes for chromosonal damage. But it has to be said that, since these examinations are invasive, they may not be acceptable to workers and they may even carry some health risk in themselves. It is likely that this unsatisfactory state of affairs will gradually change and that, in the future, simple tests will become available that are of value in predicting increased cancer risk.

However, for the present, the most important functions of a work's medical officer is to look for patterns of health changes in groups of workers and to relate these to accurate information on exposure collected by the hygienist. Vigilance in this area can bring forward the date when cancer and other health hazards are first recognized.

Unfortunately, some work's medical officers, even today, simply sit and wait for problems to come to them and are not really trained to anticipate or actively look for problems while they are still in their early stages.

\section{Need to keep good records of both exposure and health effects}

It goes without saying that the maintenance of records of details of exposure and health effects and the ready accessibility of these records can greatly facilitate pattern recognition. Moreover, with the trend towards fewer and fewer workers being required in manufacturing processes, there is a need for standardized record collection and storage systems so that data from different factories and different companies can be combined for the purposes of epidemiologic investigation. 


\section{The role of epidemiology as an investigative tool}

Recent years have seen the evolution of epidemiology as a primary investigative tool - I must admit to having reservations about this development. In the best hands it can uncover previously unsuspected hazards, as for example the increased risk of nasal cancer among cabinet makers. However, there are many poor epidemiologic methods and inadequately trained epidemiologists about. Retrospective epidemiology is full of pitfalls, particularly because multiple factors are implicated in the causation of most cancers, and it is simply not possible to control for them all, particularly if they have yet to be identified. Broadly speaking, the retrospective case-referent (case-control) study is increased in plausibility if the cancer site or kind is unusual, if the risk is great, if it is possible and reliable to distinguish between exposed and unexposed individuals, and if there are large groups of exposed and unexposed persons available to study. These conditions were fulfilled for the risk of mesothelioma in asbestos workers, but, because of small numbers and because individuals are likely to undergo mixed exposure to chemicals, they are not often fulfilled in the chemical industry. Epidemiology has done little more than muddy the waters in relation to saccharin or formaldehyde.

\section{The future}

There is no magic formula for the future. Exposure to low levels of suspect or known carcinogens and to agents of unknown carcinogenic potential is bound to go on occurring, and there is bound to be continuing pressure to reduce maximal permissable exposure to proved carcinogens. For chemicals for which there is no more than suspicion based on laboratory tests, we must ensure that regulatory action is based on good science, sound judgement, and common sense, rather than on the machinations of those with vested interests, of ambitious lawyers, or of the lunatic fringe. In responding to such pressure, we must strive to keep a sense of proportion. Since less than $10 \%$ of all cancers are seemingly due to occupational factors, even turning the world upside down with safety precautions against actual and suspected carcinogens would only marginally affect the present human cancer burden.

\section{References}

1. Cordier JM, Fievez C, Lefevre MJ, Serrin A. Acroostéolyse et lésions cutanées associées chez deux ouvrier affectés au nettogage d'autoclaves. Cah Méd Trav 4 (1966) 3-39.

2. Creech JL, Johnson MN. Angiosarcoma of liver in the manufacture of polyvinyl chloride. J Occup Med 16 (1974) 150-151.

3. Doll R. The epidemiology of cancer. Cancer 45 (1980) 2475-2485.

4. Doll R, Peto R. The causes of cancer: Quantitative estimates of avoidable risks of cancer in the United States today. J Natl Cancer Inst 66 (1981) 1191-1308.

5. Haenszel W. Studies on migrant populations. J Chronic Dis 23 (1970) 289-291

6. Health and Safety Executive. Trends in mortality, 1951-75. Her Majesty's Stationery Office, London 1978.

7. International Agency for Research on Cancer. Asbestos. Lyon 1977. (IARC monograph on the evaluation of carcinogenic risk of chemicals to man, number 14).

8. Kociba RJ, Keyes DG, Lisowe RW, Kalnins RP, Dittenber DD, Wade CE, Gorzinski SJ, Mahle NH, Schetz BA. Results of a 2-year chronic toxicity and oncogenic study in rats ingesting diets containing 2, 3, 5 -trichlorphenoxyacetic acid $(2,4,5-\mathrm{T})$. Food Cosmet Toxicol 17 (1979) 205-221.

9. MacMahon B, Cole P, Brown J. Etiology of human breast cancer: A review. J Natl Cancer Inst 50 (1973) $21-42$.

10. Roe FJC, Bär A. Enzootic and epizootic adernal medullary proliferative disease in rats: The influence of dietary factors which affect calcium absorption. Hum Toxicol 4 (1985) 27-52.

11. Tucker MJ. The effect of long-term food restriction on tumours in rodents. Int J Cancer 23 (1979) 803-807. 